INTER NATIONAL MONETARY FUND
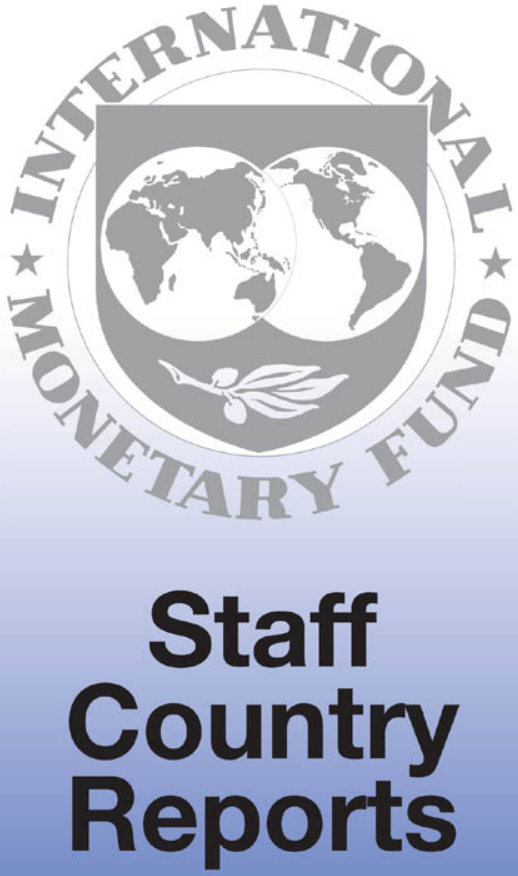


\section{Sweden: Financial Sector Assessment Program Update-Technical Note on Household Indebtedness: Implications for Financial Stability}

This technical note on Household Indebtedness: Implications for Financial Stability was prepared by a staff team of the International Monetary Fund as background documentation for the periodic consultation with the member country. It is based on the information available at the time it was completed in September, 2011. The views expressed in this document are those of the staff team and do not necessarily reflect the views of the government of Sweden or the Executive Board of the IMF.

The policy of publication of staff reports and other documents by the IMF allows for the deletion of market-sensitive information.

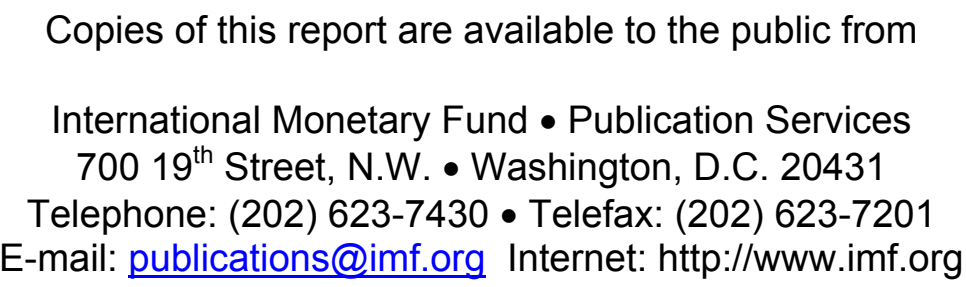

\section{International Monetary Fund Washington, D.C.}


This page intentionally left blank 
FinAnCial Sector Assessment Program Update SWEDEN

HOUSEHOLD INDEBTEDNESS: IMPLICATIONS FOR FINANCIAL STABILITY

TECHNICAL NOTE

SEPTEMBER 2011

INTERNATIONAL MONETARY FUND

MONETARY AND CAPITAL MARKETS DEPARTMENT 
Glossary

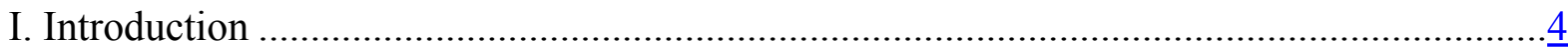

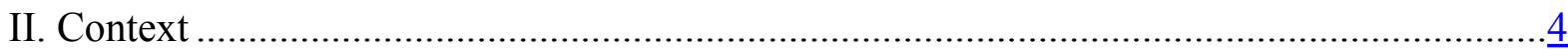

III. Overview of Household Balance Sheets ........................................................................

A. Swedish Households' Financial Position...............................................................

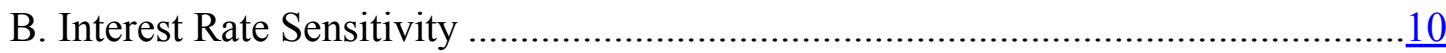

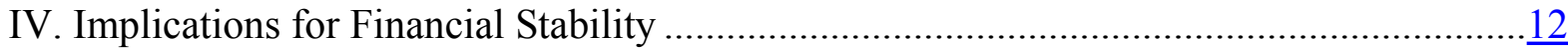

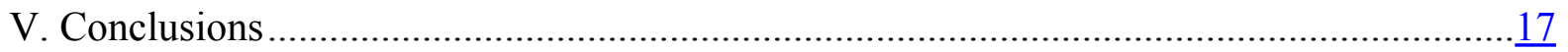

Figures

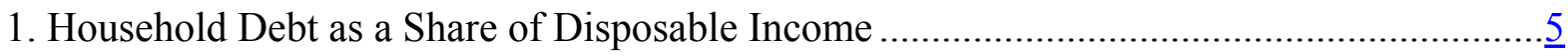

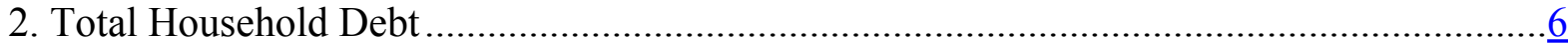

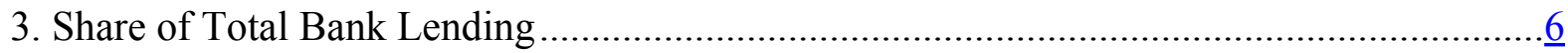

4. LTV Ratios by Age, Income and Debt Outstanding .......................................................

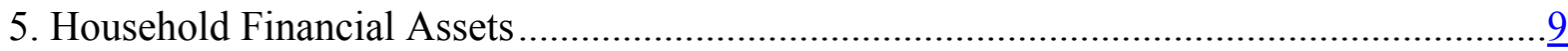

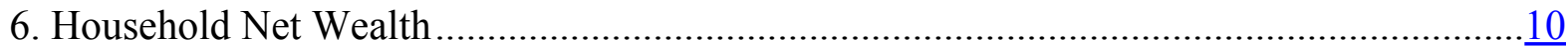

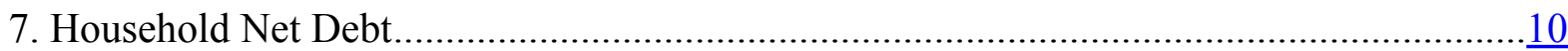

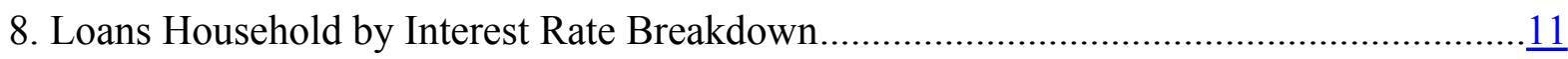

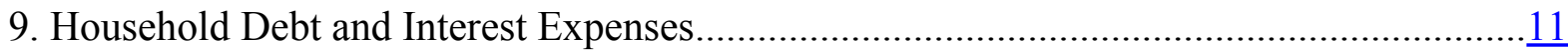

10. SBAB Share of Loans Portfolio by Risk Class................................................................14

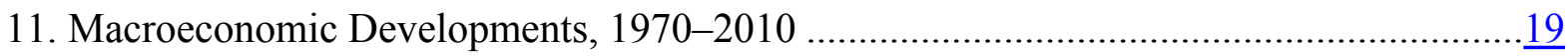

12. House Price (x-axis) and Household Debt, 1990-2010 (y/y change).................................

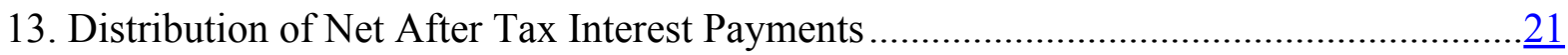

Boxes

1. Factors Explaining the Increase in House Prices and Household Debt .................................

2. Housing Finance - Sweden's Covered Bonds Market ....................................................15

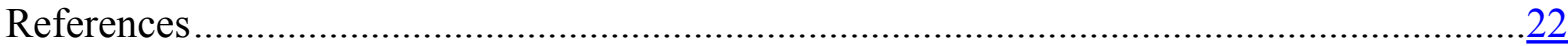




\section{GLOSSARY}

BO Bostads Obligationer (Sweden's Housing Credit Institutions)

BKN Swedish National Housing Credit Guarantee Board

CDS Credit Default Swap

EU European Union

FI Finansinspektionen (Swedish FSA)

FSR Financial Stability Report

FSAP Financial Sector Assessment Program

LTV Loan to Value

LGD Loss given default

NDO National Debt Office

NPL Nonperforming loan

PD Probability of Default

RUTH The Riksbank's Inquiry into the Risks In the Housing Market 


\section{INTRODUCTION ${ }^{1}$}

1. As elsewhere, Swedish household debt has risen to record levels over the past two decades accompanied by rising house prices, prompting concerns about sustainability and the implications for financial stability. Alongside, lending to the household sector has increased markedly at the expense of other sectors in the economy. Hence, the banking system is significantly more exposed to the household sector-with 35 percent of total loans outstanding in 2010, compared to 18 percent in 1995.

2. The rise in household debt and the banking system's increased exposure to mortgage debt, suggest vulnerabilities associated with changes in the macroeconomic environment, including a possible downward adjustment of house prices, as has occurred elsewhere in Europe. In theory, macroeconomic shocks could heighten banking sector credit risks through their impact on household balance sheets, either directly or indirectly through feedback loops between the real and financial sectors. This could be triggered by either one or a combination of the following factors: negative shocks to household income and rising unemployment, a rapid increase in interest rates, and a decline in real estate prices.

\section{This note explores the implications for financial stability of household} indebtedness by evaluating the household sector's financial position, as well as Sweden specific institutional features to ensure resilience of the financial system. We conclude that while on the face of it, risks appear similar to elsewhere in Europe-where recent housing booms and busts have produced banking sector stresses - several Sweden-specific institutional and structural features of the mortgage market provide safety buffers, helping to lower the direct vulnerability of the financial sector.

\section{Context}

4. As in other advanced economies, there has been a significant run-up of household debt in Sweden during the last two decades (Figure 1). Since the mid-1990s, the ratio of household debt to personal disposable income has risen steadily, surpassing its previous peak to reach a record 163 percent in 2010. This increase in household debt is unprecedented in Swedish history both in magnitude and in duration, but it is consistent with trends elsewhere among advanced economies.

\footnotetext{
${ }^{1}$ Prepared by Rita Babihuga (EUR)
} 
Figure 1. Sweden: Household Debt as a Share of Disposable Income

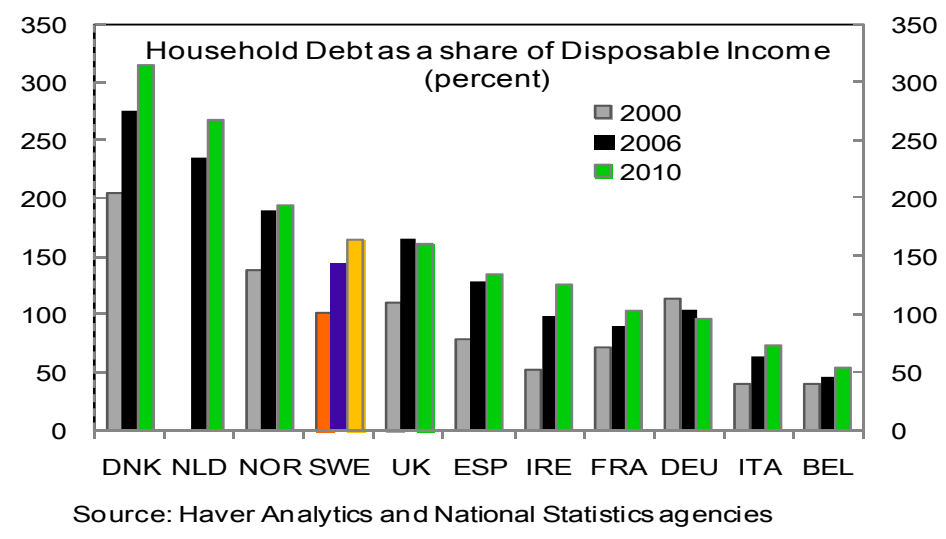

5. The long term upward trend in household debt has occurred in the context of structural shifts in the macroeconomic environment. After experiencing a severe economic and financial crisis during 1991-93, Sweden rebuilt its economy by implementing drastic reforms. In particular, the fixed exchange rate regime was abandoned for a freelyfloating regime, and a rules-based fiscal framework and inflation targeting regime were introduced.

\section{The result has been two decades of strong macroeconomic performance, which} has allowed for the increase in household indebtedness (Figure 11). From 1995-2007, growth averaged close to $3 \frac{1}{2}$ percent, exceeding the European average of $2 \frac{1}{2}$ percent; the fiscal position over-performed by regional standards, with fiscal surpluses and low debt; and inflation declined. The introduction of inflation targeting in 1993 by the Riksbank led to a secular decline in interest rates that improved debt affordability. On the back of strong growth, the stock market rose rapidly, contributing to the financial wealth of households, while low and stable inflation reduced the likelihood of future interest-rate volatility, all of which contributed to households' increased appetite for leverage.

7. Mortgage debt has driven the rise in total household debt (Figure 2). While other categories of household debt have risen slightly over the past decade, mortgage debt makes up the bulk of household debt and has dominated the increase in household borrowing. Mortgage debt as a share of household income has risen from 73 percent in 1996 to 145 percent in 2010, compared to other personal debt, which has risen from 15 percent to some 20 percent over the same period. 


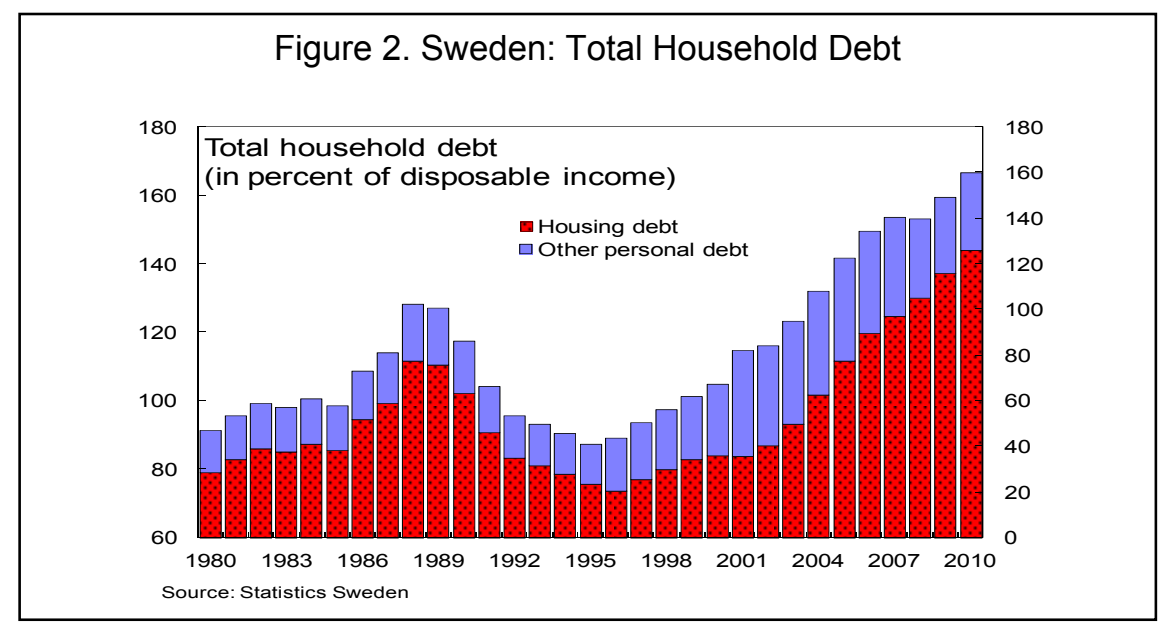

8. As elsewhere, increased household borrowing and rising house prices appear interdependent. The increase in household debt and house prices share the same root causes and the evidence suggests the two phenomena are highly correlated (Figure 11 and Box 1), including through feedback effects - the continued house price rise has in turn fueled borrowing. Although LTV ratios have increased, there is a limit to how much banks would be willing to lend to households without some commensurate increase in collateral. Conversely, faced with increasing house prices relative to their incomes, households have inevitably had to borrow more. What is more, as discussed above the large share of mortgage debt in total household debt further exacerbates the link between house price and household debt dynamics.

\section{However, unlike the previous housing and credit boom-from 1980-90-there} has been a marked shift in the banking system's exposures. The previous boom occurred alongside a construction boom and an increase in banks' lending to the commercial real estate sector, a category that was responsible for the bulk of banks' loan losses in the ensuing banking crisis. Since then, the composition of bank lending has shifted, with banks' taking on more household debt and reducing exposures to the corporate sector (Figure 3). The current housing boom is marked by the absence of a construction boom (see Box 1).

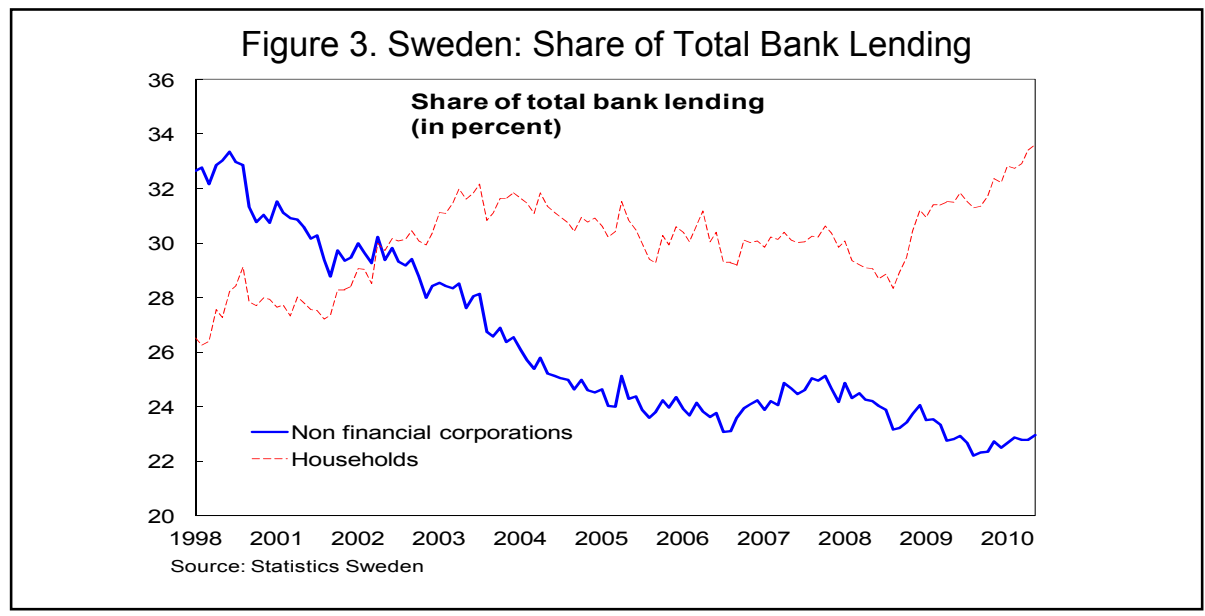




\section{Box 1. Factors Explaining the Increase in House Prices and Household Debt}

Recent empirical analysis by the Riksbank (RUTH) concludes that Swedish house prices are largely explained by fundamental factors, but finds no evidence of overvaluation. Most of the increase in house prices since 1995 is attributed to higher household income and lower user costs - disposable income explains roughly $1 / 2$ of the increase; and lower interest rates explain roughly 35 percent; and household financial wealth explains some 10 percent of the increase. The residual suggests that prices are roughly 20 percent above their long term trend. To the contrary, a study carried out by the Swedish National Housing Finance Board in February 2011 concluded that house prices were overvalued by some $20-25$ percent. The following factors have been important for driving up house prices and household debt:

\section{Demand side factors:}

- A low interest rate environment and rising household income in the context of stronger macroeconomic outcomes have lowered costs and raised borrowers' demand for credit.

Strong economic performance, stock market gains and historically low interest rates have raised household disposable income, financial wealth and debt payment capacity.

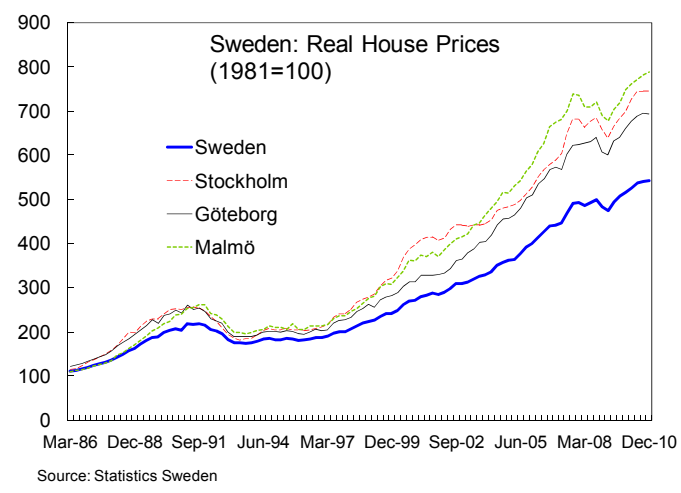

- Changes in the tax regime - the abolition of property, wealth, inheritance and gift taxes - together with the 30 percent mortgage interest deduction, have eased access to housing, including for the young who have benefitted from intergenerational wealth transfers.

- Moreover, a long term demographic shift towards metropolitan areas - associated with a shift in the structure of the economy towards the service sector-has put pressure on the limited stock of housing. In fact, house price appreciation has been concentrated around large cities like Stockholm, Malmo and Gothenburg, while prices elsewhere have fallen.

\section{Supply side factors:}

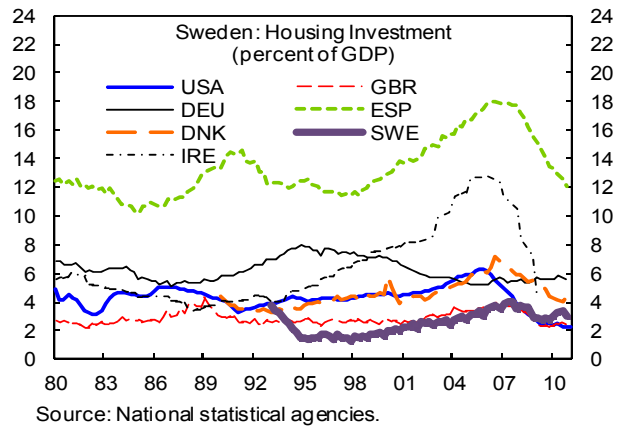

- Sweden's house price rise is unique in that increased demand has not been met by an increase in supply. Housing supply remains structurally low. Possible factors explaining this include: the rent regulation system, prevalent in the main cities, combined with land scarcity and onerous procedures for developers which have contributed to a structurally low level of residential investment.

\section{Financial sector factors:}

- Financial innovations have eased access to credit and reduced financial constraints for first time buyers. Increased competition among mortgage lenders has resulted in a wider array of mortgage products now widely available to Swedish households. These include "interest only" loans or "amortization-free" mortgage loans which allow the deferral of the payment of the principal for a given period of time or even until the end of the loan.

The introduction of covered bonds legislation in 2004 transformed the covered bonds market and bolstered mortgage lending. Since then, there has been a significant pick-up in mortgage lending (Box 2). 
10. Moreover, LTV ratios have risen. The average LTV ratio rose to 55 percent at end2010 from 10 percent in 1995. Prior to the 85 percent LTV cap imposed in October 2010, the average LTV ratio on new-lending had risen to 75 percent for dwelling, according to FI's 2009 mortgage survey. Moreover, 12 percent of new borrowers were found to have an LTV above 90 percent, while one third had an LTV above 85 percent. Furthermore, according to banks' own rules LTV ratios varied between 75 and 95 per cent of the market value (or the estimated market value). Most banks also offered a first mortgage, which is limited to $75-85$ per cent of the market value, and a second mortgage for the amount exceeding this limit.

\section{Higher LTV ratios have increasingly been concentrated among younger buyers}

(Figure 4). Alongside the rising share of younger home - usually first time-buyers, their loan-to-value ratio also rose to 70 percent in 2009. Hence, loan size and risks have increased significantly for households that entered the housing market more recently. However, firsttime homebuyers account for a very small percentage of homeowners. Moreover, more than 95 percent of the households who own their own homes have done so for at least two years and have seen a drop in their loan-to-value ratio.

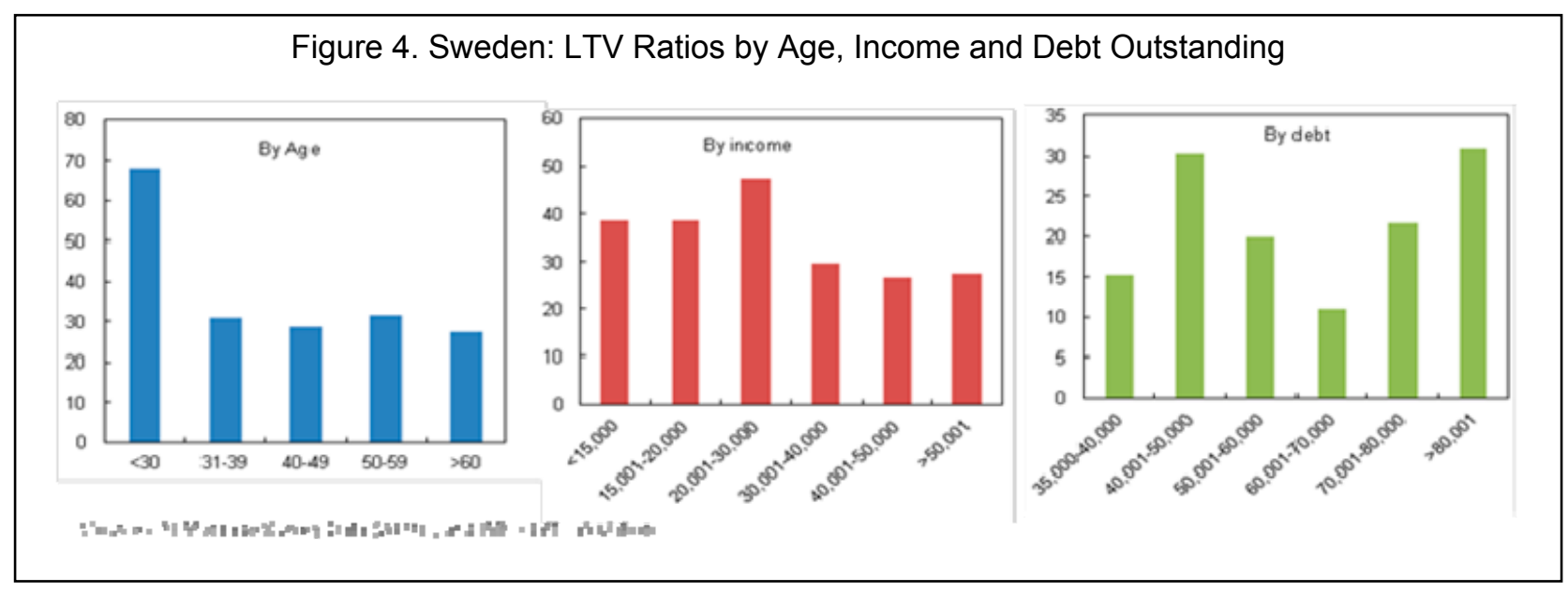

12. These trends have largely been unaffected by the recent global financial crisis and the ensuing domestic recession. The increase in household debt and house prices slowed briefly in 2008, at the onset of the global financial crisis, but then picked up pace soon thereafter, rising rapidly in 2009-10. In fact, Sweden was one of a few advanced countries where house prices did not adjust downwards during the crisis. With the imposition of an LTV cap on mortgages in October 2010, and the Riksbank embarking on a monetary tightening cycle in July 2010, the housing market appeared to slow somewhat during the first quarter of 2011. Nevertheless, Sweden has had one of the most buoyant housing markets among advanced countries during 2009-10.

\section{The continued housing market buoyancy despite the 2008-09 crisis can largely} be attributed to crisis response policies and strong capital inflows. The authorities responded to the crisis with an aggressive mix of stabilization policies - an expansionary 
monetary policy brought the policy rate to its nominal floor; fiscal stimulus supported employment and household incomes'; while financial policies provided vital capital and liquidity support to the financial sector. These helped to stabilize the banking system and buffer household demand from the externally driven shock to the economy.

\section{Riksbank financial sector support measures enabled continued lending to}

households. In particular, as part of its package of emergency measures during the crisis, the Riksbank expanded its collateral policy framework by accepting covered bonds as collateral - a facility which currently remains active. This played a key role in restoring the functioning of the covered bonds market and ensuring continued financing of mortgages. Throughout the crisis, bank lending to the household sector continued uninterrupted.

\section{OVERVIEW OF Household Balance SheEtS}

\section{A. Swedish Households' Financial Position}

15. Wealth buffers are significant (Figure 5). From a debt stock perspective, household leverage - the ratio of debt to net wealth - is only slightly above historical norms, as growth in borrowing has been largely offset by an increase in housing and financial wealth. In fact, Swedish households have a significant net wealth buffer of more than 200 percent of disposable income. Hence, on the aggregate level, households would be well placed to weather a housing market correction. One caveat has to do with fact that more than $1 / 2$ of households' financial wealth is in equities, whose buoyancy has been driven by the same macroeconomic factors responsible for rising house prices and household debt. Hence, a downward correction of house prices would likely feedback to equity markets through its adverse effects on the macro-economy,

Figure 5. Sweden: Household Financial Assets

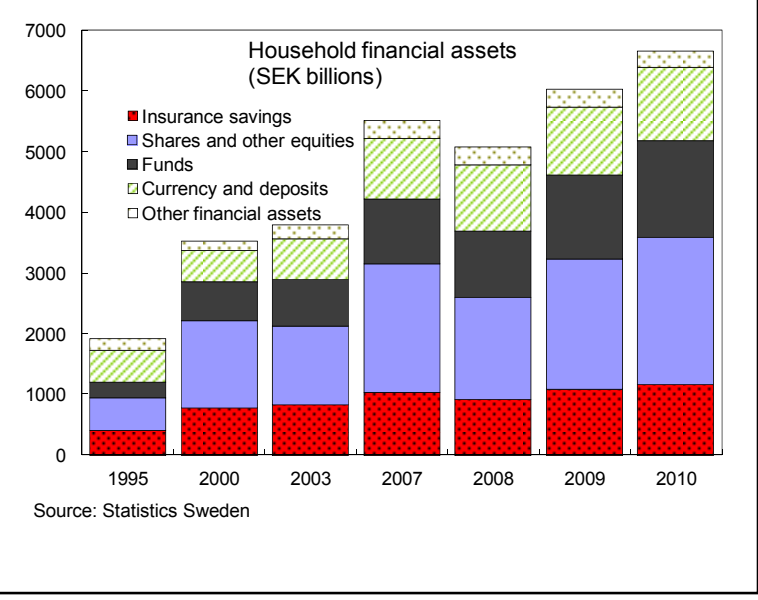
which would in turn reduce households' wealth buffers. Households' non-equity financial buffer was roughly 75 percent of disposable income at end-2010.

\footnotetext{
${ }^{2}$ As part of its employment support measures during the crisis, the government introduced a new tax deduction at the end of 2008 of up to 50 percent on housing renovation and rebuilding, which has since been raised to SEK 50,000 (EUR 5,000) per house owner and year. This tax deduction has been popular and widely used, and thus, has provided support to mortgage lending activity and in particular the construction sector during the economic downturn.
} 


\section{Increased financial risks related to the changing composition of household net} wealth are less prominent in Sweden. Shifts in the composition of household balance sheets in advanced countries have left the household sector more exposed to financial risks. In particular, the increased share of housing on the asset side has raised the proportionate impact of house prices on overall household net wealth and left balance sheets less liquid ${ }^{3}$. Also, as net debt has risen - in part reflecting higher gross debt as well as the declining share of fixed income assets (including deposits and money market funds) relative to equity and housing - the net negative impact of higher interest rates on household cash flows has increased. Swedish households are less vulnerable in this regard-despite the increase in housing values, real assets still account for less than $1 / 4$ of total household net wealth. Moreover, while net debt has been rising since the mid-1990 - mainly reflecting the fact that gross debt has risen faster than liquid assets - it declined during the recent financial crisis, as households switched back into relatively safer and more liquid assets (Figures 6 and 7).

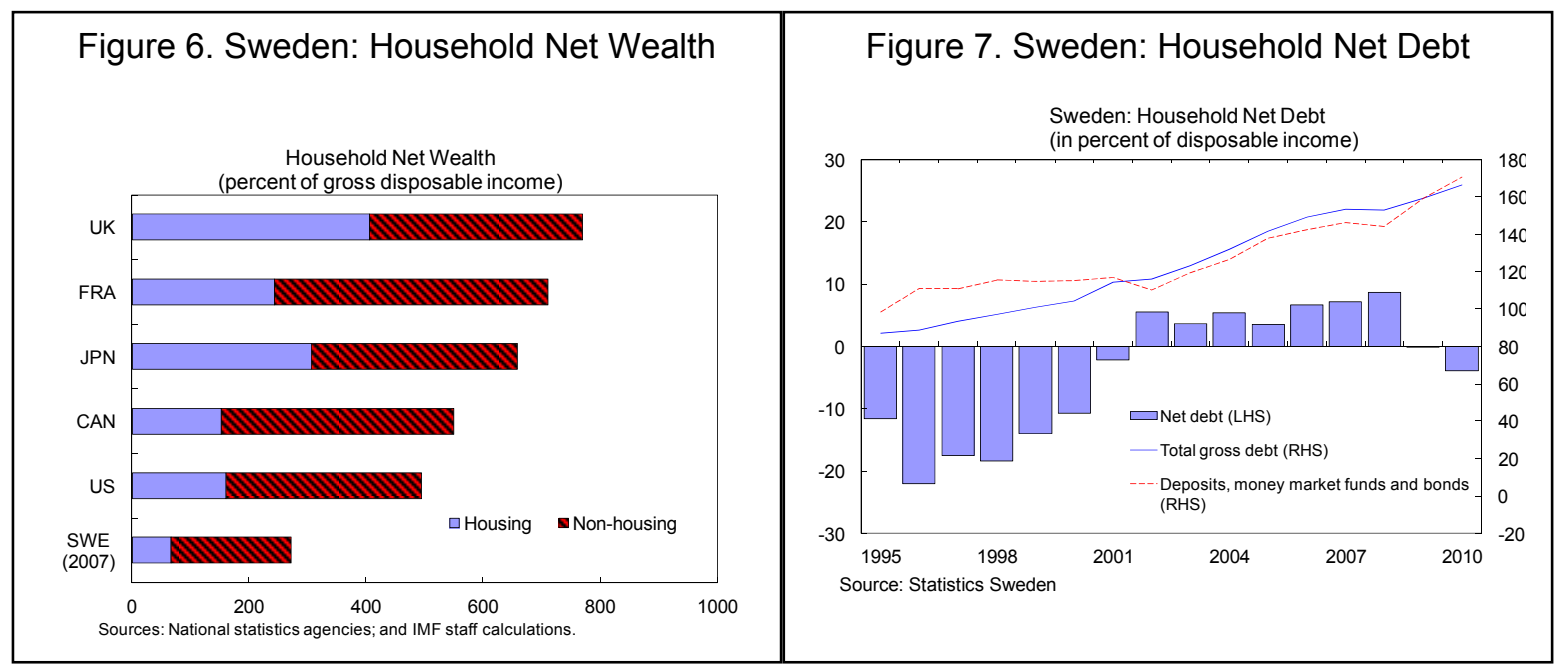

\section{B. Interest Rate Sensitivity}

17. Variable-interest rate mortgages have increasingly become the norm (Figure 8). At the end of the 1990s, the share of loans with variable interest rate rose to roughly 40 percent of new mortgage loans and this share remained constant until 2007. However, in

\footnotetext{
${ }^{3}$ In the case of Sweden, data on housing wealth are unavailable beyond 2007 due to abolition of the household wealth survey in 2007.
} 
2008 the share of loans with variable interest rates on new lending increased to over 60 percent, reflecting expectations of future falling interest rates. Variable rate loans peaked at 62 percent of the total outstanding stock in early 2010, with fixed rates ( $1-5$ years) accounting for 28 percent and fixed rates ( $>5$ years) accounting for 10 percent.

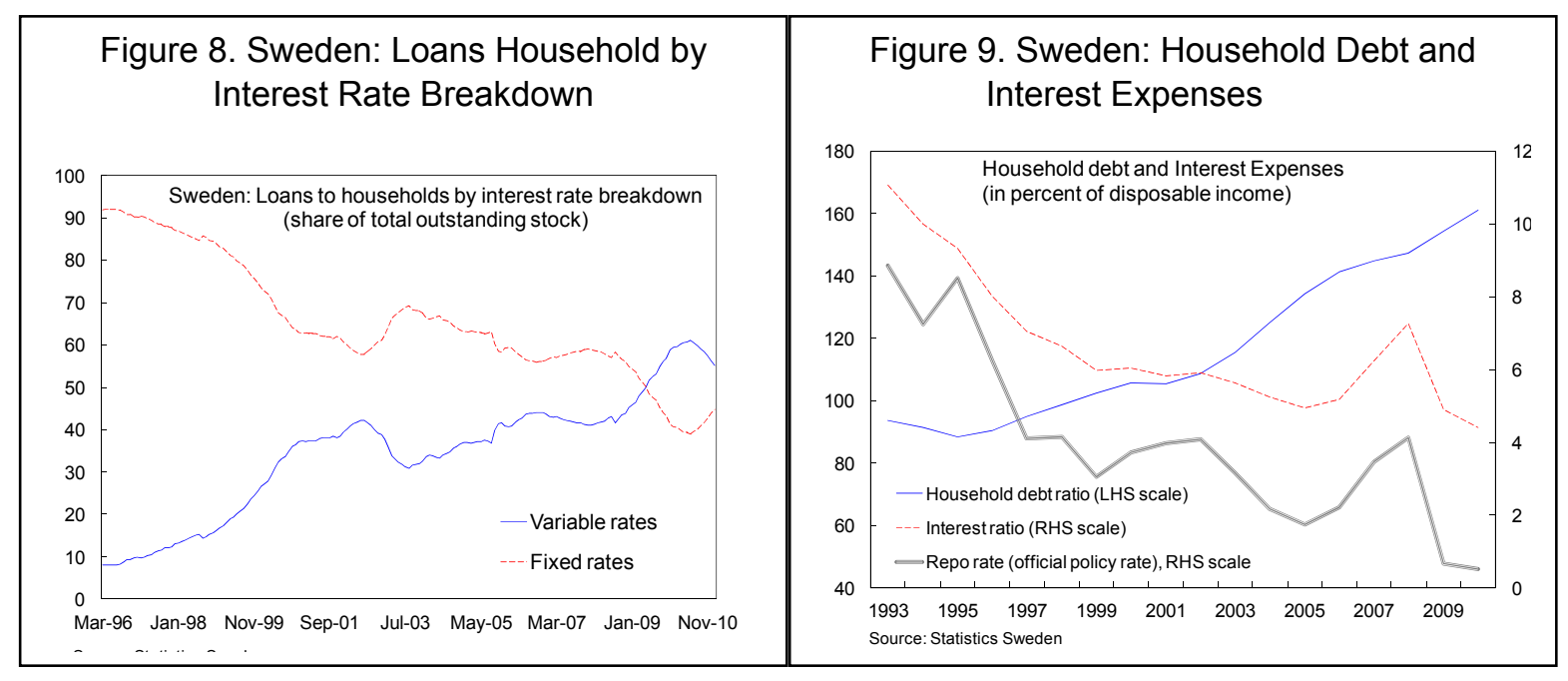

\section{The structural long term decline in interest rates has been key to affordability}

(Figure 9). While household debt has increased relative to both income and assets, the interest cover or debt service ratio of households has fallen on the back of a long term decline in interest rates. Hence, the increase in household indebtedness has been offset by the decline in borrowing rates, so that on average, households have not devoted a greater share of their income to debt service than in the past. However, with interest rates at historical lows and set to rise further as the Riksbank withdraws monetary stimulus, debt service will rise further as mortgage rates increase with the policy rate. As in 2006-08 when policy rates rose, interest ratios have been on the rise since mid-2010, when the current monetary tightening cycle began.

19. Household affordability has declined of late. Swedbank's affordability index tracks households' ability to pay. The index is 100 percent when the household uses 15 percent of its income before taxes (roughly 25 percent of disposable income) to service debt (interest and amortization). When the index is higher than 100, this indicates that households are better placed to afford their houses. Since 2008, the index has fallen below 100, reaching 96 in 2010Q4.

20. These broad trends mask key variation across the population, suggesting that younger and less secure households are more vulnerable to interest rate fluctuations 
(Figure 13). Estimates of the S-curve ${ }^{4}$, derived from household survey data confirm the trends observed in aggregate data:

a. Household interest ratios follow official policy rates quite closely. According to Figure 13a, the interest ratio declined for all households from 1994-2008, but rose from 2006-08, in line with monetary tightening;

b. Younger borrowers are more sensitive to interest rate changes than the average household. Comparing figure 13a and 13b, it appears that when interest rates rose in 2008, younger borrowers paid more interest as a share of their income compared to the average household. This is most likely because younger borrowers have lower incomes than the average household, and are also in the early stage of wealth formation. It is also consistent with evidence that LTV ratios are highest among younger borrowers;

c. Similarly, vulnerable borrowers appear more sensitive to interest rate fluctuations. Figures $13 \mathrm{a}, 13 \mathrm{c}$ and $13 \mathrm{~d}$ have similar distributions, implying that like younger borrowers, borrowers prone to illness and unemployment experienced a sharper decline in interest payments from 1994-2008. As in the case of younger borrowers, these borrowers likely have fewer assets and higher LTV ratios than the average household;

d. Older borrowers are less sensitive to interest rate changes than any other cohort. They pay lower interest than both the average household and younger borrowers. Older borrowers appear to have experienced the smallest change in their interest ratio from $1994-2008 .{ }^{5}$

\section{The bulk of the debt stock is held by households with high net worth. The} majority of housing debt is held by high income households, who also hold the bulk of real and financial assets.

\section{IMPLICATIONS FOR FINANCIAL STABILITY}

22. Household debt has risen significantly, but overall, household balance sheets remain in good shape, with a substantial rise in the value of real and financial assets offsetting the

\footnotetext{
${ }^{4}$ The S-Curve is a cumulative distribution, in this case, illustrating households' interest ratio.

${ }^{5}$ Net interest ratios of older borrowers are likely influenced to a larger extent by holdings of financial wealth and hence, interest incomes, which may explain why net interest ratios are lower than the average.
} 
increase in debt. Moreover, most of the debt stock is held by households that can afford to service it.

\section{Riksbank stress tests conclude that credit risks stemming from household}

indebtedness are low. Stress tests carried out on micro survey data of household wealth find that low income households present the highest financial risks, given that they hold the least amount of wealth buffers. However, these households represent a small proportion-roughly 6 percent - of the total indebted households in the survey and hold only about 6 percent of total household debts. The projected loan losses associated with a default by vulnerable households amount to 0.9 percent, significantly higher than average mortgage losses, but still on the low side.

24. Similar exercises yield comparable results. Updating this analysis beyond 2007 was not possible given that the survey on household wealth was discontinued ${ }^{6}$. However, the Riksbank has recently made an attempt using a one-time mortgage survey carried out in 2009. ${ }^{7}$ Here too, loan losses stemming from the household sector are found to be negligible. In three different scenarios involving single factor shocks to the interest rate, household income and unemployment, banks' credit losses are found to be small compared to total lending. Within this, the highest credit losses are found to stem from interest rate shockscredit losses rise to 1.9 percent in the interest rate shock scenario, 1.3 percent in the household income shock scenario, and 0.8 percent in the unemployment shock scenario ${ }^{8}$.

\section{Furthermore, stress tests of the banking carried out in the context of the FSAP}

Update confirm these results. Stress tests of banks' portfolio broken down by exposures to the aggregate household sector, as well as the financial and non-financial corporate sectors conclude that households pose the lowest credit risks. However, these results depend critically on conservative assumptions about loss-given-default - these LGD assumptions are based on historical averages of mortgage losses, which have historically been low in Sweden.

\footnotetext{
${ }^{6}$ This survey was previously administered by Statistics Sweden on behalf of the Fiscal authorities. It was discontinued in 2007 along the repeal of the wealth tax.

${ }^{7}$ The mortgage survey was carried out by FI over a 3 day period in late September 2009, which represents the seasonal peak of new lending. It covered new mortgage lending over this period for banks which together represent 90 percent of the Swedish mortgage markets. The sample contains information about the borrower's debts and disposable income, the market value of the property and the banks' "left-to-live-on" calculations.

${ }^{8}$ See Jonsson et. al., "Household Indebtedness - consequences for the banks' credit losses and financial stability”, in RUTH (2011)

${ }^{9}$ See Sweden FSAP Update: Technical Note on Stress Testing (2011)
} 
26. The combination of a number of Swedish specific factors explains why household lending has historically not generated significant losses for the financial system:

a. Credit quality is high: The highly regulated covered bonds market through which mortgages are financed provides incentives for lenders to engage in selective mortgage origination (Box 2).

a. Direct and life-long personal liability: This feature of Swedish bankruptcy law makes it difficult for borrowers to "walk away" from their debt. By law, a borrower is personally liable for life, even after a default and foreclosure procedure has been initiated by the bank.

b. Social security: A well-developed and generous social welfare system implies that households' ability to service debt does not necessarily deteriorate during periods of unemployment.

c. No buy-to-let market: The absence of a speculative "buy-to-let" market due to a highly regulated rental market and tenant owner subletting restrictions has prevented the development of a speculative bubble.

27. Moreover, there is no evidence that household credit quality has deteriorated in recent years (Figure 10). The continued rise in house prices and household debt in recent years, together with the increase in new-buyers entering the housing market do not appear to have affected credit quality.

Figure 10. Sweden: SBAB Share of Loans Portfolio by Risk Class

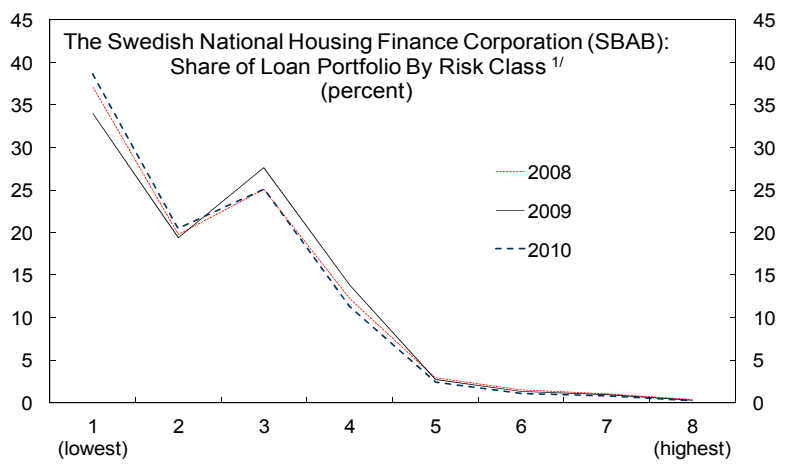

Source: SBAB reports

$1 /$ Data are only for SBAB, the state owned mortgage finance company, the fifth largest mortgage issuer. 


\section{Box 2: Housing Finance—Sweden's Covered Bonds Market}

The Swedish Covered Bond Act, which took effect on 1 July 2004, bolstered the Swedish mortgage market by introducing a new method of funding for Swedish financial institutions. Previously, bonds issued by Swedish housing credit institutions (Bostads Obligationer, BO) presented only a general claim on the mortgage credit institution's assets. Besides, the legally stipulated balance sheet structure, there was no preferential claim for BO holders. Under the Covered Bond Act, investors are secured by double recourse - meaning that they have recourse to both the collateral pool backing the specific covered bond program and to the estate of the bank on its default. Since then, the outstanding stock of covered bonds has risen from 40 percent of GDP to over 160 percent of GDP.
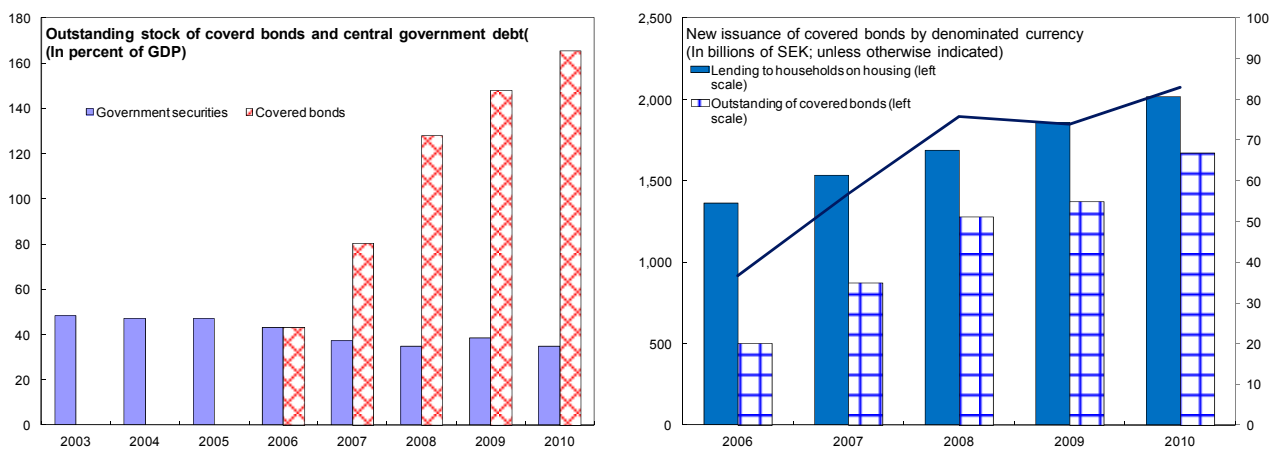

The covered bond law transformed the Swedish market into a market similar to other EU covered bond markets. The legal framework for Swedish covered bonds does not include a specialist bank principle. All Swedish banks are entitled to issue covered bonds. Comparable to the new Pfandbrief Law in Germany, a special license by the FI is required. To qualify for a license, the issuer has to comply with the following: (i) property valuation principles; (ii) present value calculations of assets and liabilities; (iii) interest rate risk with stress tests in yield curve shifts; (iii) currency risk; and (iii) minimum swap counterpart rating levels.

As a result, Swedish banks' reliance on covered bond funding has also increased rapidly. The amount of covered bond issuance as share of total mortgage lending rose has doubled to 80 percent since 2006. Also, funding costs of covered bonds are cheaper than alternative means, including senior debt issuance, which has contributed to lower mortgage interest rates, in turn stimulating mortgage demand.

Credit quality of the cover pool is high. Mortgage loans backed by residential, commercial and agricultural property are eligible as collateral. The LTV requirements are 75 percent for residential property, 70 percent for agricultural property, and 60 percent for commercial real estate. Mortgage loans that are in arrears for more than 60 days do not count as collateral for Swedish covered bonds. The cover pool, which may also contain public sector loans and supplemental assets, is dynamic, meaning that the quality of loans included in the pool must always comply with regulations, including LTV and NPL requirements. Moreover, the cover pool is frequently monitored by FI through an independently appointed inspector.

Prior to the law, Swedish mortgage institutions were not subject to any matching requirements between assets and liabilities. According to the Swedish Covered Bond Law, the issuer of Swedish covered bonds must segregate a cover pool, which must at all times exceed the nominal value and the net present value of the claims that covered bond holders have against the issuer. Moreover, the collateral must withstand symmetric interest rate shocks (shifts of the yield curve by 100bps). Issuers are also required to hedge against currency risk through over-collaterization - the present value of covered assets must exceed the present value of covered bonds by an amount equivalent to a 10 percent shift in the currency. 


\section{Box 2: Housing Finance—Sweden's Covered Bonds Market (concluded)}

Despite the dual recourse mechanism, the Swedish covered bonds market froze up during the global crisis. In late-2008 to early-2009, covered bond spreads over treasury securities yields widened significantly, and demand for covered bonds, in both primary and secondary markets, fell sharply. The decline in investor appetite was particularly evident in euro markets, as evidenced by the sharp decline in euro-denominated covered bond issuance. In response, the Riksbank began to accept a wider range of covered bonds as collateral, the NDO purchased covered bonds in exchange of treasury securities to support covered bond markets, and the government introduced the bank debt guarantee program.

Accordingly, covered bonds - and their originators, banks - would not be immune to further funding shocks. In particular, a fall in house prices would be capable of reducing investor appetite for covered bonds, leading to higher interest rates or even refinancing risks. Furthermore, although covered bonds are protected from liquidity risks due to asset and liability matching requirements, this merely means that final mortgage borrowers bear liquidity risks. Thus banks would most likely indirectly shoulder risks, were markets to be hit by shocks.

Legal Overview of Nordic Covered Bonds

\begin{tabular}{|c|c|c|c|c|}
\hline & Sweden & Denmark & Finland & Norway \\
\hline Legislation & Law of July 1, 2004 & DFBA and MCLMBA & Finnish Covered Bond Act & $\begin{array}{l}\text { Act on Financing Activity and } \\
\text { Financial Institutions No. } 40 \text { of } \\
\text { June } 10,1988\end{array}$ \\
\hline Potential Collateral & $\begin{array}{l}\text { Residential and commercial } \\
\text { mortgages; and public debt }\end{array}$ & $\begin{array}{l}\text { Residential and commercial } \\
\text { mortgages; Shipping loans for } \\
\text { commercial banks only }\end{array}$ & $\begin{array}{l}\text { Mortgages; public sector debt; } \\
\text { and shares in Finnish Real } \\
\text { Estate Corporation }\end{array}$ & $\begin{array}{l}\text { Residential and commercial } \\
\text { mortgages; public debt }\end{array}$ \\
\hline Asset Allocation & Common register & $\begin{array}{l}\text { Varoious mortgage and public } \\
\text { registers }\end{array}$ & $\begin{array}{l}\text { Common register for mortgages } \\
\text { and public collateral }\end{array}$ & Common or seprate register \\
\hline Substitute collateral & Up to $20 \%$ & Yes & $\begin{array}{l}20 \% \text { (up to } 30 \% \text { with special } \\
\text { approval from the supervisor) }\end{array}$ & $\begin{array}{l}\text { Maximum } 20 \%, 30 \% \text { for a } \\
\text { limited period if authorized by } \\
\text { the supervisor }\end{array}$ \\
\hline $\begin{array}{l}\text { Restrictions on certain } \\
\text { asset classes }\end{array}$ & $\begin{array}{l}\text { Commercial mortgages capped } \\
\text { at } 10 \% \text { of total pool }\end{array}$ & No & No & No \\
\hline $\begin{array}{l}\text { Geographical scope for } \\
\text { public assets }\end{array}$ & OECD & Not applicable & OECD & OECD \\
\hline $\begin{array}{l}\text { Geographical scope for } \\
\text { mortgage assets }\end{array}$ & EEA & $\begin{array}{l}\text { Denmark, Greenland, Faroe } \\
\text { Islands; other countries with } \\
\text { approval from the supervisor }\end{array}$ & OECD & OECD \\
\hline LTV limit residential & $75 \%$ & $80 \%$ & $75 \%$ & $75 \%$ \\
\hline LTV limit commercial & $60 \%$ & $60 \%$ & $60 \%$ & $60 \%$ \\
\hline Basis for evaluation & Market value & Mortgage lending value & Prudent market value & Market value \\
\hline Valuation Check & Regular examination & No explicit regulation & Regular examination & Regular examination \\
\hline Special Supervision & Yes, FI & Yes, DSFA & Yes, Fiva & Yes, Kredittilsynet \\
\hline $\begin{array}{l}\text { Protection against } \\
\text { mismatching }\end{array}$ & $\begin{array}{l}\text { Nominal coverage, NPV } \\
\text { coverage }\end{array}$ & $\begin{array}{l}\text { Yes, general or specific balance } \\
\text { principles govern restrictions on } \\
\text { maximum mismatches possible }\end{array}$ & $\begin{array}{l}\text { Nominal coverage NPV } \\
\text { coverae, } 12 \text { month cash flow } \\
\text { coverage, stress testing, } \\
\text { liquidity management }\end{array}$ & $\begin{array}{l}\text { Law stipulates that cash flows } \\
\text { should be matched narrowly }\end{array}$ \\
\hline $\begin{array}{l}\text { Protection against credit } \\
\text { risks }\end{array}$ & Issuer must replace NPLs & $\begin{array}{l}\text { Not compulsory, implicit } \\
\text { regulations }\end{array}$ & Readjustment of valuation & Issuer must replace NPLs \\
\hline
\end{tabular}


28. Nevertheless, a housing market correction could entail funding risks for the financial sector. Whereas the increased financing of mortgages via the covered bonds market has helped reduce credit risks related to household debt, it has increased banks' exposures to the covered bonds market. In the event of a housing market correction, investor appetite for covered bonds would decline, raising refinancing risks for banks and leading to higher mortgage interest rates. Such a seizing-up of the covered bonds market occurred during the 2008-09 crisis, brought on by the global financial crisis and investor retrenchment of lending to banks. At the time, the Riksbank stepped in to accept a wider range of covered bonds as collateral, and the NDO issued T-bills in excess of the borrowing requirement. Borrowing from the T-bill issues was mainly invested in reverse repos in covered bonds, which helped to ease strains in that market.

\section{Conclusions}

29. House prices and household indebtedness have risen to record levels, but do not appear to present significant credit risks to the financial sector. The robustness of household balance sheets and concentration of debt within high net worth segments of the population imply lower risks for banks. Moreover, the Swedish Covered Bonds Act of 2004 was instrumental in structuring the covered bond market along the lines of other successful covered bonds markets in Europe. This development was important for the growth of mortgage lending as well as guaranteeing the high quality of mortgage loans.

\section{Furthermore, several Swedish-specific factors explain the high credit quality of} household mortgages. Household debt in Sweden is full-recourse, meaning that borrowers have a life-long personal obligation for their debts. Most importantly, as noted by several banks during the FSAP Update discussions, household debt is implicitly backed by public finances. A well-developed system of social benefits-including unemployment insurance for up to three years and support for the long term unemployed - provides households with buffers during economic downturns. Due to the legal stipulation of personal liability for debts, households would rather reduce other consumption than default on their debts, and generous public support enables them to maintain their "capacity to pay" even during periods of unemployment.

\section{Moreover, the structural shift in the composition of banks balance sheet since} the mid-1990s suggests a commensurate shift in financial risks to the public sector. Credit risks are low ultimately because borrowers are hedged by the public sector. As such, alongside the structural shift over the last two decades towards increased exposures to the household sector, has occurred a parallel shift in financial risks ultimately borne by the public sector. As discussed earlier, this has been made possible by Sweden's strong macroeconomic performance since the crisis of the early-1990s, and in particular, the strengthening of the fiscal position. 
32. Nevertheless, a disorderly correction of house prices still has the potential to destabilize the financial system through the funding channel. As discussed, the growth of the covered bonds market, including to foreign investors entails risks of retrenchment of lending, including from domestic factors such as a housing bust. 
Figure 11: Sweden: Macroeconomic Developments, 1970-2010
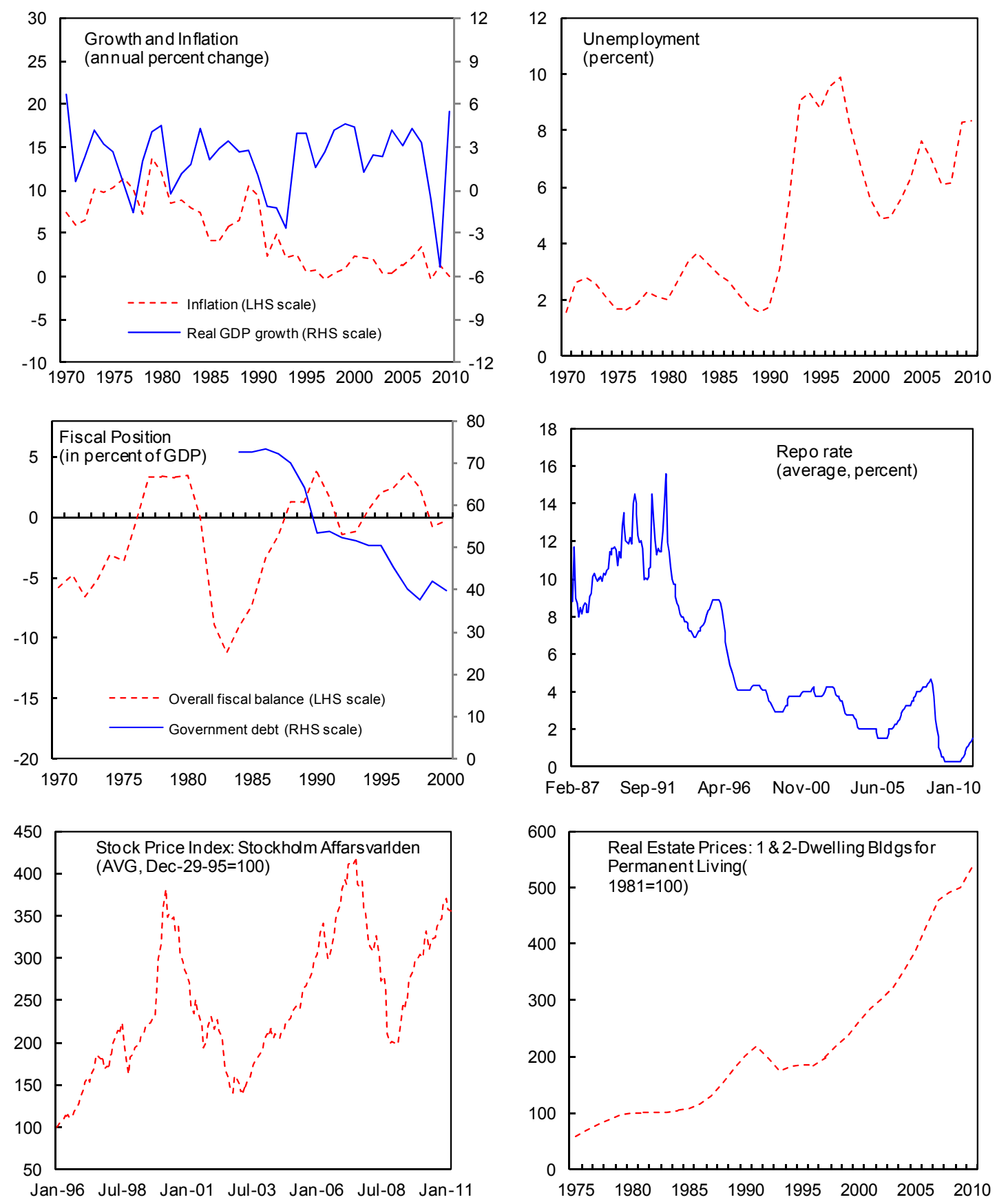

Sources: Statistics Sweden, Riksbank, Haver Analytics and World Economic Outlook. 
Figure 12: Sweden: House Price (x-axis) and Household Debt, 1990-2010 (y/y change)
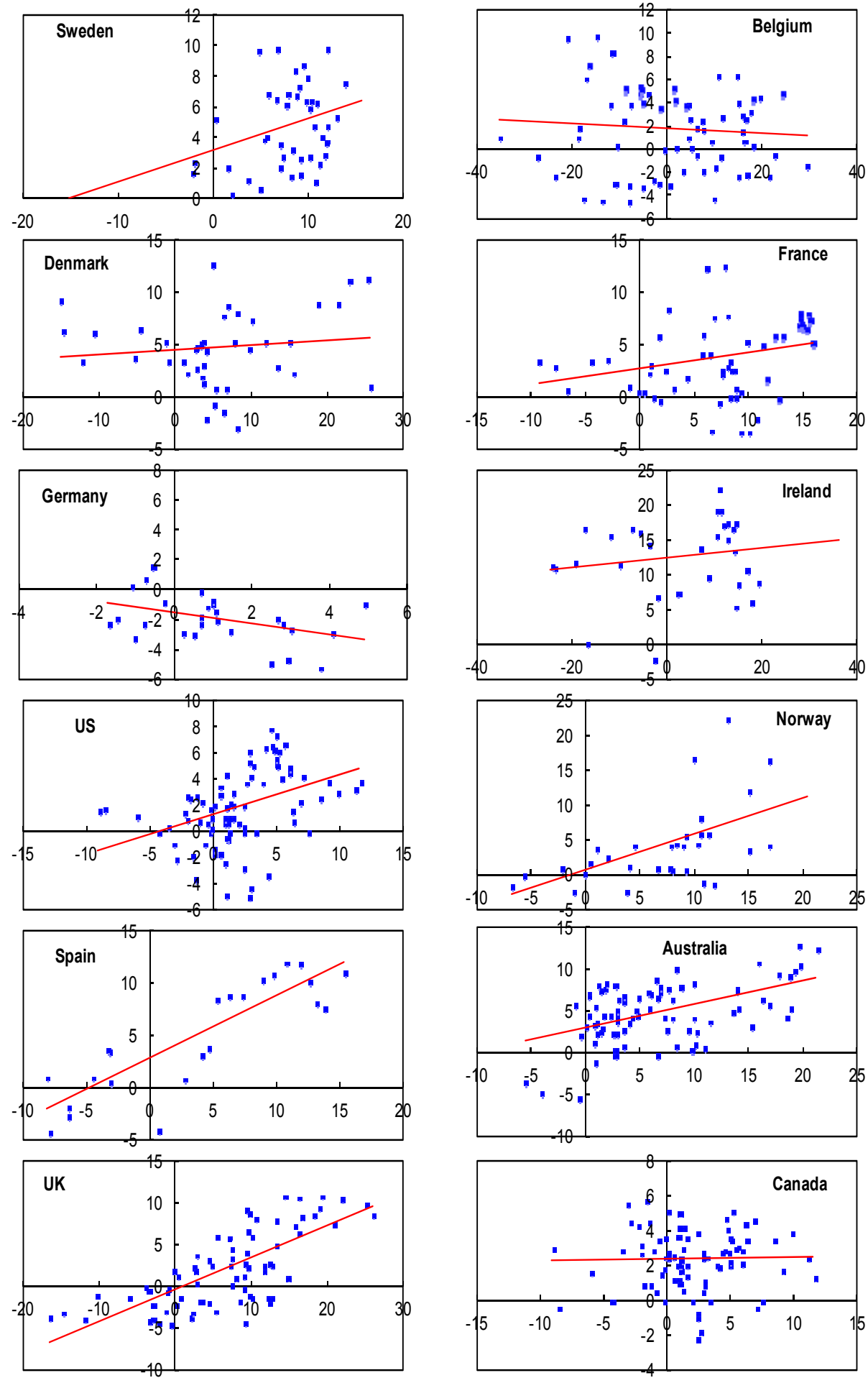

Source: Haver Analytics and staff calculations 
Figure 13. Sweden: Distribution of Net After Tax Interest Payments (in percent of disposable income)

\section{3a. All Households}

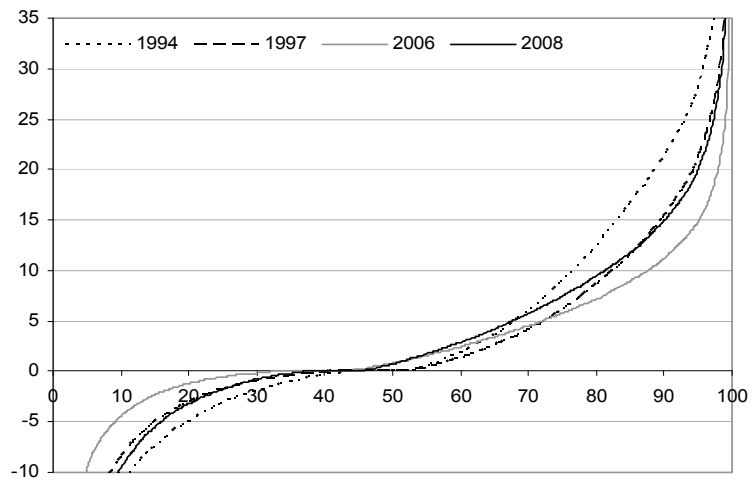

13c: Households with household head above 65 years old

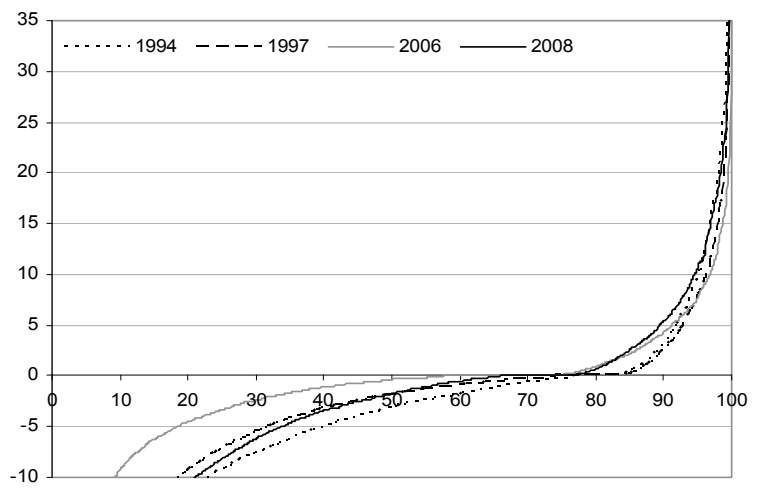

13e. Household with household head that has received unemployment benefit of at least SEK 20,000

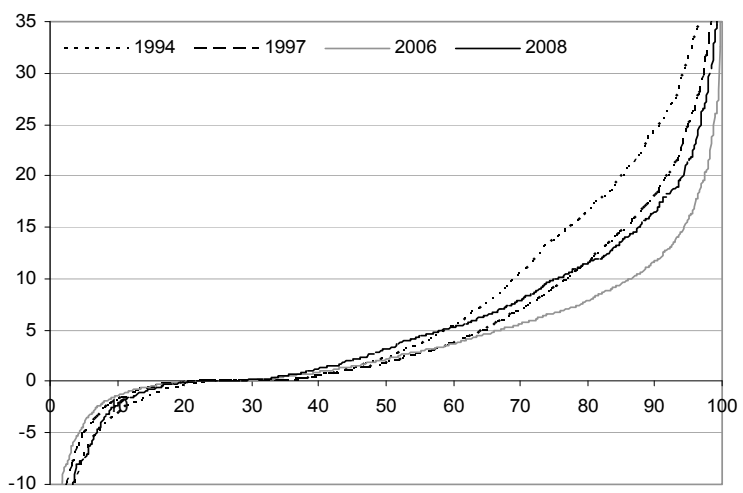

13b. Households with household head $25-40$ years old

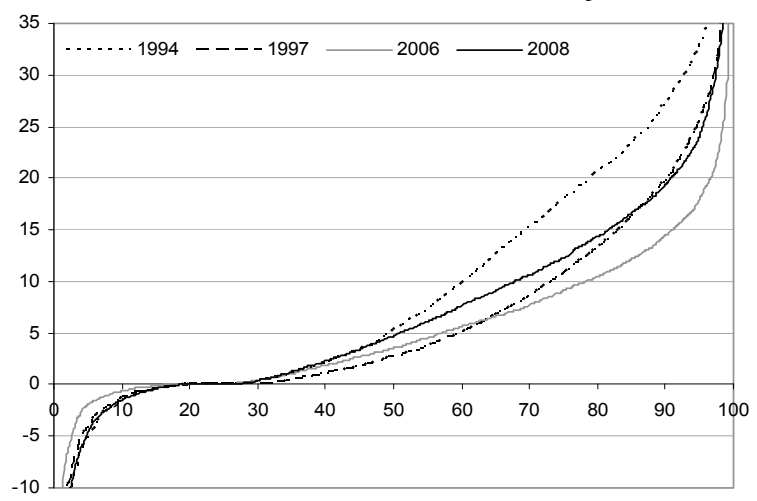

13d. Households with household head that has received unemployment benefit or compensation for sickness

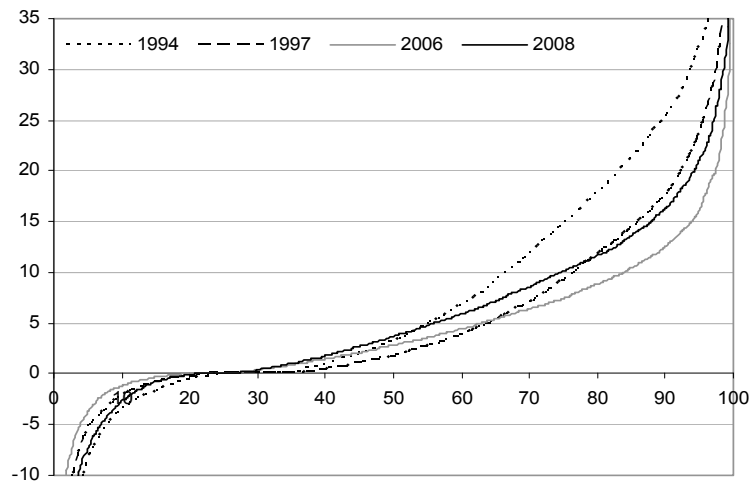

Source: Statistics Sweden, The FASIT-model with data HINK/HEK for the years 1994, 1997, 2006 and 2008. 


\section{REFERENCES}

Financial Stability Report, 2007:1, Sveriges Riksbank , Financial Stability Report, 2007:2, Sveriges Riksbank

Girouard N, M Kennedy and C André, 2007, "Has the rise in debt made households more vulnerable?" OECD Working Papers, no 535, 3 January.

Glick, Reuven, and Kevin J. Lansing, 2010, "Global Household Leverage, House Prices and Consumption," Federal Reserve Bank of San Francisco, Economic Letter

Johansson, Martin, W., and M. Persson, 2006, "Swedish households' indebtedness and ability to pay - a household level study." Riksbank Working Paper.

Persson, Mattias, 2009, "Household indebtedness in Sweden and implications for financial stability - the use of household-level data." BIS Papers No. 46.

Riksbank's Commission of Inquiry Into Risks on the Swedish Housing Market-RUTH, 2011, Sveriges Riksbank

Schich, Sebastian, and J. Ahn, 2007, "Housing Markets and Household Debt: Short term and long term risks.” OECD. 